\title{
Vashakidze Iamze
}

MIA Academym Georgia

\section{Towards some issues of teaching Georgian as a state language to the minorities of Georgia (Azerbaijanis and Armenians)}

\begin{abstract}
The main theme of the work is teaching Georgian as a state language to ethnical minorities residing in Georgia. The research is based on the presentation of pedagogical observation, which is developed within the framework of the Georgian Language Education Program. The results of the research based on personal experience will provide practical service to the people involved in the teaching of the state language.
\end{abstract}

Key words: Teaching the state language; Pedagogical observation

\section{Introduction}

At the current stage of development of Georgia, in the process of formation of the country as an independent state, special interest is paid to teaching Georgian as a state language to ethnic minorities to overcome the language barrier in order to integrate them into Georgian society and to find a job in state organizations etc. In this regard functioning of the educational programs of the Georgian language is significant in Georgian Universities.

The goal of the presented work is to discuss pedagogical observations worked out on the basis of my own practice (an intermediate participant teaching Georgian to Azerbaijanis and Armenians, who did not study in Georgian schools). These pedagogical observations were developed over a number of years at Ivane Javakhishvili Tbilisi State University for the English language and Arabian speakers and at the MIA Academy, in the process of teaching the Georgian language to Armenian and Azerbaijani students.

The process of obtaining analytical material can be divided into three stages; these are: preliminary observations, data collection and analysis. This research is focused on examination of specific methodological ideas for the final generalization through the examples obtained in the teaching process.

Three main issues will be discussed in this article:

- Georgian language sounds;

- Verbs of different constructions;

- Forms of personal anddemonstrative pronouns.

Before moving to the specific material, I would like to point out that together with Professor T. Putkaradze I am working on atextbook, which focuses on the teaching of Georgian literary language to nonGeorgian people living in Georgia and, also, to Georgian people living in other countries. The discussion and relevant exercises below present part of our unpublished manual.

\section{Teaching Georgian language sounds}

Armenian and Azerbaijani students living in Georgiahave difficulties pronouncing Georgian words. In this respect, Azerbaijanis face a greater challenge. For them (unlike Armenians), it is difficult to perceive and pronounce Georgian sharp sounds. Therefore, based on our practice, we consider the rich material of Georgian toponymsand anthroponomy to be a good resource for phonetic exercises. We believe that this will 
facilitatestudents' adequate perception of the Georgian pronunciation system as well as the establishment of relevant sounds in the perceptual base of Azerbaijanis and Armenian students (Japaridze, 1975).

In our guide, particularly, the first four lessons at A-1 level are devoted to the learning of the Georgian alphabet. The material is distributed according to the frequency and origin of the use of speech sounds:

- First lesson: Vowels: a, e, i, o, u and sonorant consonants: v, m, n, r, l;

- Second lesson: Pair consonants: z, s, ž, š, g, x;trigraph consonants: g, k', k

- Third lesson: trigraph consonants: d, t', t; j, c', c; j̆, č', č;

- Fourth lesson: trigraph consonant: b, p', p; single consonants: q, h.

Examples from the third lesson are discussed below. There are 11 academic and practical exercises. In the first exercise, the student should learn to write the compositions ofthree consonants: d, t', t; j, c', c; $\breve{j}$, č́, č. For this the first grade notebook (with four lines) is used which shows the direction of writing based on three drawings (the beginning, the middle stage and the end of the letter).

The second exercise is set constructed according to listening, speaking and writing strategies. The student should listen to two video materials andas directed, should repeat the speech sounds: d, t', t; j, c', c; j, č', čpracticed in the first video. Having listened to the second video footage, the student should write down the appropriate letters (in the first video the sounds of speechare recorded together with their graphemes whereasin the second video footageonly therecorded material is given);

The aim of the third exercise is to teach the above taught sounds of speech with various vowel combinations, namely:

In the first part of the exercise, the student should give the syllables containing these consonants with vowels.
a) da - t'a - ta
ja $-c^{\prime} a-c a$
j̆a - č'a - ča
b) de - t'e - te
je - c'e - ce
je - č'e - če
c) di - t'i-ti
ji - c'i-ci
ji - č'i - či
d) do - t'o - to
jo - c'o - co
jo - č'o - čo
e) du - t'u - tu
$\mathrm{ju}-\mathrm{c}^{\prime} \mathrm{u}-\mathrm{cu}$
ju - č'u - ču

In the second part of the exercise, the student should listen to the audio recordingand in writing underline the pair syllables recorded in the audio file.
a) da - t'a
ta - t'a
b) de - t'e
te - t'e
c) di - t'i
ti - t'i
d) do -t'o
to - t'o
e) du - t'u
tu - t'u
f) ja-ca
c'a - ca
g) je - c'e
ce - c'e
h) ji - c'I
ci - c'i
i) jo - c'o
co - c'o
j) ju - c'u
$\mathrm{cu}-\mathrm{c}^{\prime} \mathrm{u}$
k) ja - č'a
ča - č'a
1) う̌e - č'e
če - č'e
m) ji - č'i
či - č'i
n) jo - čo
čo - č'o
o) ju - č'u
ču - č'u

The fourth exercise is focused onreading strategy. The student should read the Georgian words with the sounds discussed above, or proper names and surnames spread in the Caucasus: 

d: Dariko, Dodo, Medea; Dadiani, Adeišvili;
t': K'e t'evani, T'ornike, Gv t'iso; T'arkhnišvili, Da t'ašvili;
t: Taso, Khatia, Konstantine; Xoštaria, Tatišvili;
j: Jijia, Jajuli, Ujilauri, Jijiguri, Mejmariašvili;
c': C'i c'ino, Nu c'a, C'otne; C'u c'kiri je, C'e c'xlaje;
c: Kocia, Cicola; gurckaia, Cocoria, Cockolauri;
j: juna, jar ǰi, jemali; ji k'ia, jmuxaje;
č': č'iora, xvi č'a, va č'e; č'ankseliani, č'a č'ua;
č: či čia, či čiko, čola; čav čavaje, čiaureli.

According to the fifth exercise, a combined work should be done. Specifically, this exercise includes listening to Georgian toponyms, recognition and insertion of the missed letter in the word, and pronunciation of the word. Compared to the previous exercise, difficult phonetic assignment appears here, specifically the student should be able to determine the difference between consonants thethree consonants (toponyms are sorted first, sequence of triple and then the opposite pairs):

$$
\begin{aligned}
& \mathrm{d}-\mathrm{t}^{\prime}-\mathrm{t} \text { :darkve t'i, t'ortiza, tur c'xi; } \\
& \text { d - t':t'orsa, der č'I, ikor t'a; } \\
& \mathrm{d}-\mathrm{t} \text { : gudani, ku čatani, idumala; } \\
& \mathrm{t}^{\prime}-\mathrm{t}: \mathrm{t}^{\prime} \operatorname{mog} \mathrm{vi} \text {, tanjia, t'irkna; } \\
& \text { j - c' - c: jevri, c'i c'xvari, ca ğveri; } \\
& \text { j-c: cir k'vali, jirula, cerovani; } \\
& \text { c - c':c'xemna, caḡvli, c'ana; } \\
& \text { у - č' - č: ǰandara, č'xari, čarnali; } \\
& \text { j - č: vaki ǰvari, ča čara k'I, no ǰixevi; } \\
& \text { j - č':č'o čxa t'i, ǰixan ǰiri, č'ome t'i; } \\
& \text { č' - č:čan čaxa, č'an čxalo, čoroxi. }
\end{aligned}
$$

The task of the sixth exercise is to read the Georgian toponyms, then to listen to the audio recording, to number the audio files and pronounce them distinctly:

\begin{tabular}{llll}
\multicolumn{1}{c}{ 1) } & 2) & 3) & 4) \\
sac'xvitauri & ukane t'I & jigideri & ujlouri \\
cicamuri & k'un c'a & cela t'I & cavkisi \\
jin čvisi & macevani & c'ixisjiri & jolevi
\end{tabular}

The seventh exercise is a dictation involving listening and writing down theGeorgian toponyms containing newly acquired sounds:

$\begin{array}{llc}\text { Karcaxi } & - & \text { k'ircina } \\ \text { Čvana } & - & \text { č'k'valeri } \\ \text { č'oxatauri } & - & \text { čotori } \\ \text { čiora } & - & \text { jimara }\end{array}$

The eighth exercise is oriented on listening as well as on the guiding strategy by deduction. The student listens to the audio recording and points out the words which are not recorded on the audio file(names, surnames and the pairs of toponyms).

\section{Names / Surnames}

1) č'ač'anije - čavčanije

2) jinčaraje - č'inč'alaje

\section{Troponins}

jima t'i - jimi t'i

c'un č'xa - žo šxa 

3) jajamia - curcumia
juari - čeri
4) nodari - o t'ari
čoroxi - č'iruxi
5) c'i c'ino - cicola
sadaxlo - t'oxliauri

The ninth exercise is filling outa grid withthe acquired letters, in which the learner should find and circle the names of the Georgian rivers: Mtkvari, T'ergi, Liaxvi, Mejuda, T'ort'la.

\begin{tabular}{|l|l|l|l|l|l|l|l|l|}
\hline $\mathrm{t}^{\prime}$ & $\mathrm{b}$ & $\mathrm{a}$ & $\mathrm{s}$ & $\mathrm{l}$ & $\mathrm{m}$ & $\mathrm{v}$ & $\mathrm{t}^{\prime}$ & $\mathrm{x}$ \\
\hline $\mathrm{x}$ & $\mathrm{o}$ & $\check{c}^{\prime}$ & $\mathrm{e}$ & $\mathrm{t}^{\prime}$ & $\mathrm{e}$ & $\mathrm{s}$ & $\mathrm{e}$ & $\mathrm{b}$ \\
\hline $\mathrm{i}$ & $\mathrm{t}$ & $\mathrm{r}$ & $\mathrm{u}$ & $\mathrm{v}$ & $\mathrm{j}$ & $\check{c}^{\prime}$ & $\mathrm{r}$ & $\mathrm{i}$ \\
\hline $\mathrm{l}$ & $\mathrm{m}$ & $\mathrm{j}$ & $\mathrm{t}^{\prime}$ & $\mathrm{c}$ & $\mathrm{u}$ & $\mathrm{a}$ & $\mathrm{g}$ & $\mathrm{r}$ \\
\hline $\mathrm{i}$ & $\check{c}^{\prime}$ & $\mathrm{k}$ & $\mathrm{n}$ & $\mathrm{l}$ & $\mathrm{d}$ & $\mathrm{s}$ & $\mathrm{i}$ & $\mathrm{t}$ \\
\hline $\mathrm{a}$ & $\mathrm{s}$ & $\mathrm{a}$ & $\mathrm{c}^{\prime}$ & $\mathrm{t}^{\prime}$ & $\mathrm{a}$ & $\mathrm{x}$ & $\mathrm{m}$ & $\mathrm{m}$ \\
\hline $\mathrm{x}$ & $\mathrm{j}$ & $\mathrm{t}^{\prime}$ & $\mathrm{s}$ & $\mathrm{r}$ & $\mathrm{x}$ & $\mathrm{d}$ & $\mathrm{i}$ & $\mathrm{c}$ \\
\hline $\mathrm{v}$ & $\mathrm{k}$ & $\mathrm{u}$ & $\mathrm{a}$ & $\check{c}^{\prime}$ & $\mathrm{t}$ & $\mathrm{t}^{\prime}$ & $\mathrm{v}$ & $\mathrm{u}$ \\
\hline $\mathrm{i}$ & $\mathrm{x}$ & $\mathrm{m}$ & $\mathrm{t}$ & $\mathrm{k}$ & $\mathrm{v}$ & $\mathrm{a}$ & $\mathrm{r}$ & $\mathrm{i}$ \\
\hline $\mathrm{s}$ & $\mathrm{a}$ & $\mathrm{d}$ & $\mathrm{m}$ & $\mathrm{k}$ & $\check{c}^{\prime}$ & $\mathrm{k}$ & $\mathrm{a}$ & $\mathrm{a}$ \\
\hline
\end{tabular}

The tenth and eleventh exercises are composed based on the famous method - international words, specifically: according to the tenth exercise, the language learner should restore the missing sound in the given international term:
(1. $\mathrm{t}^{\prime}, \breve{\mathrm{j}}, \check{c}^{\prime}, \mathrm{t}, \mathrm{d}$;
2. $\check{c}^{\prime}, t, d, \breve{j}, t^{\prime}$
3. $\check{c}^{\prime}, \mathrm{d}, \breve{\mathrm{j}}, \mathrm{c}^{\prime}, \mathrm{t}$;

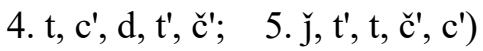

1.

- eoria

- insi

kau-uki

is-oria

a-resati
2.

iani-ari

vi-rina

-rama

lo-ia

mi-I
3.

-alma

kor-oni

-okeri

-entri

invent-ari
4.

ske- č'i

-unami

li-eri

a-leti

-elo
5.

-ungli

me-odi

av-onomia

-eki

-ilindri

According to the eleventh exercise, the learner should choose syllables from the second column to complete the given international words in the first column.

$\begin{array}{ll}\text {-nozavri } & \text { ti } \\ \text { c'is-na } & \text { to } \\ \text { t'ea- } & \text { č'i } \\ \text {-udo } & \text { c'en } \\ \text { make- } & \text { t'ed } \\ \text {-ni } & \text { tri } \\ \text {-novniki } & \text { di } \\ \text { ka-ra } & \text { ter } \\ \text { li-zia } & \text { ji } \\ \text { redak'-ri } & \text { ji }\end{array}$


As can be seen from the discussed materials, in the exercises composed by us, the number of the Georgian anthroponyms and toponyms is much higher than that of international words. We do not have anything against the approved method of teaching international words, but, on the other hand, we believe that it is more advisable to learn the Georgian language speech phonics based on the onomastic basis.

\section{Teaching of verbs of different constructions}

At the A1 level it is required to read, perceive and reproduce, orally or in a written form, information regarding the following topics: a person's identity, age, nationality, place of residence, studies, practical activities, family etc. (Dosela, 2013, p. 108-112). To achieve this result, it is necessary to teach different types of verbs. The first verb, naturally, is "To be" (I am, you are, she/he/it is...) and the learner, accordingly, follows the sequence of personal pronouns: I - we, you - you, she/he/it - they. Information about the family, for example, requires teaching the verb "To have". In the case of the first and the second persons there is no change in the verb construction, but the situation in the third person changes and Azerbaijani and Armenian students ask questions about this aspect. In addition, the questions arise when the topic of the different case in the third person form of personal pronouns is discussed. It is only natural that students draw parallels between Georgian and their native languages, in which, the subject always stands in one and the same form. (Naturally, here we mean an adult student with at least secondary education, who is able to perceive and learn the material based on logical understanding).

In our opinion, a difficult process of teaching the Georgian verb may become much easierif the verb forms are divided into two groups from the very beginning. Specifically, the so called V-type and M-type verbs, orverb forms with subjects expressed by V- type and M-type, which have entirely different structures: the construction of $\mathrm{M}$-variants remains unchanged. $\mathrm{S}$ appearsin the Dative case whereasO is the marker of the Nominative case. On the other hand, the construction of V-form verbsis also unchanged but only within the first series. Sis the marker of the Nominative case whereas Oappears in the Dative case.

akvs mas is (He/she has got it) - while determining the active agent in such verb, thesemantics of the verb is most important. We avoid discussing the so-called inversion, real or grammatical subject and objects, as we find it unadvisable to provide the information about this disputable grammatical issue to the learner at the level of A1 in Georgian.

Consequently, working with the students of the language competence of the level A1 in Georgian, we consider it appropriate first to pay attention to the forms of the first series, particularly, to teach the Present, the Continuous and the Future Tenses to avoid confusion and demotivation. The students should also be informed that the verb "knows" is the only exception with the subject in the Ergative case in the Present and Continuousforms (man itsis/man itsoda (he knows/ he knew it)). As the construction is changed in the Future tense, instead of V-type construction, M-type configuration appears and the subject stands in the Dative as this is characteristic of M-type construction.

It is advisable to teach the imperfect form at the last lessons of the A1 level, in particular, after the Future tense, as unlike the forms of the first series, the construction of some of the V-type verbs (so-called mid-active and active voice forms) changes in aorist. Comp:

\section{Present: He plays/He plays it /is t'amašobs//is t'amašobs mas/}

Aorist: He played/He played it /man it'amaša//manit'amaša is/

Based on the above, the language learner (within the scope of the study material) should be given information about the V-type subject constructions with changeable and unchangeable forms. In the Georgian language electronic guidelines (searched 12. 02. 2018, http://elearning.ena.ge), in the 22th lesson of A1 level the conjugated verbs "sadiloba/chama (to have dinner" /"to eat") are taught simultaneously, in Aorist and in Future tenses. The authors provide the conjugation of these verbs without personal pronouns (supposedly, to avoid the possible confusion caused by different verb constructions), but such an approach, to our mind, looks like 
learning conjugation without the subject, for the sake of the conjugation and not for building a phrase/clause and facilitating speaking activities.

\section{Teaching of the forms of Personaland Demonstrative Pronouns}

Following the experience of foreign language textbooks, at the A1 level, it is advisable to teach the bipartite system of demonstrative pronouns. Teaching the tripartite system of demonstrative pronouns instead of the bipartite system seems more effective at an initial stage and reflects the characteristics of themodern Georgian language. At the same time, taught in this way, it is not difficult to remember and is a good lexical way to enrich the material.

In addition, based on different constructions of the verbs, all the possibleforms of the third person pronouns involved in syntactic constructions should be taken into consideration from the very beginning. This will facilitate the process of building a sentence, particularly those constructed with the V-type and M-type verbs and corresponding pronouns (ob - obobo (is/isini) dsb / dsb - dson(man/mas-mat).

\section{Conclusion}

The teaching of Georgian as a state language toethnic minorities (Armenians, Azerbaijanis) living in Georgia is a new aspect of teaching in our educational space.Sharing experience will advance this difficult challenge.

1. One of the complex issues for the citizens of Georgia regarding minority issues is pronunciation of Georgian consonant clusters. Accordingly, on the basis of my teaching practice, using the rich data of the Georgian toponymics and anthroponomy names in order to make phonetic exercises seems to be the best solution. Unlikely in Armenians, ethnic Azerbaijani students have the problems of pronunciation during acquisition of the Georgian alphabet: perception and pronunciation of the ejective stops. In this particular case the exercises based on the Georgian place and anthroponomy names seems to be very helpful. This kind of approach makes them familiar with specific Georgian sounds.

2. Grouping into two big sections of the Georgian verb forms - so called "verbs with the marker v" and "verbs with the marker m" simplifies the process of teaching; these groups possess strictly distinctive constructions. In spite of the tenses, the construction of the verbs with the personal prefix $\mathrm{m}$ - is unchangeable: the subject is in the dative case and object is permanently marked with the Nominative case markers (-i/-Ø). The verbs with the personal marker affix with the marker $\mathrm{v}$ reveal the nominative construction only in the 1st series: the subject in the Nominative case and object in the Dative case. According to this, I believe that at A1 level it would be better to teach only forms of the Present, Imperfect and Future screeves (exception: manerg icis "heergative knows"). This kind of approach may avoid misunderstanding and particular problems. As for the forms of Aorist screeve, it would be advisable to teach them after future screeve forms have been mastered, as the last topic of the A1 level.

3. Teaching the tripartite system of demonstrative pronouns instead of the bipartite system seems more effective at an initial stage; also, the Ergative and Dative forms of the third personal pronouns (is-isini, man/mas-mat) should be taken into consideration at the very beginning of the GESL course; this kind of approach will help the students to analyze and realize the diversional constructions of the verbs of both the $\mathrm{v}$ - and $\mathrm{m}$ - types. 


\section{References}

E-learning course of the Georgian language. Browsed 12.02.2018; http://elearning.ena.ge/

Japaridze, Z. (1975). The main issues of perceptual phonetics. Tbilisi. "Science".

Odzeli, M. (2013). To define the level of ownership of the state language of Georgia, for civil workers and people seeking Georgian citizenship. Actual problems of Geology, II, 108-132. 